\title{
FOTOGRAFIA COMO CRENÇA
}

\section{Camila Otto}

Mestre pelo Programa de Pós-Graduação da Escola de Belas Artes da UFMG, pesquisadora, artista plástica e designer

\begin{abstract}
RESUMO
No presente artigo serão discutidos alguns conceitos relacionados aos temas “imagem”, “fotografia” e “memória”. Discorrerá também sobre a fotografia, que, muitas vezes, é vista como documento e objeto de crença. Coloca ainda em questão sua importância diante da memória, nos álbuns de família e na formação imagética do indivíduo, além de comentar o caráter dual da fotografia, que permite construir narrativas, rever histórias e propor novas abordagens e interpretações da imagem. Tudo isso será discutido a partir de VE(lar), trabalho de minha autoria.
\end{abstract}

\section{PALAVRAS-CHAVE}

Imagem, fotografia, memória, álbum de família, ambiguidade

Antes de começar, é preciso que eu me aproprie das palavras de Mia Couto, ${ }^{1}$ que tão bem diz sobre o que irei discorrer:

Meu neto, me chegue aquele álbum.

Aponta um velho álbum de fotografias pousado na poeira do armário. Era ali que, às escondidas, ela vinha tirar vingança do tempo. Naquele livro a Avó visitava lembranças, doces revivências.

Mas quando o álbum se abre em seu colo eu reparo, espantado, que não há fotografia alguma. As páginas de desbotada cartolina estão vazias. Ainda se notam as marcas onde, antes, estiveram coladas fotos. - Vá. Sente aqui que eu lhe mostro. (...)

E vai repassando as folhas vazias, com aqueles seus dedos sem aptidão, a voz num fio como se não quisesse despertar os fotografados. (...)

\footnotetext{
${ }^{1}$ Escritor moçambicano que, assim como Guimarães Rosa, ensinou-me uma nova maneira de falar ou "falinventar" o português. É biólogo, escritor e publicou diversos livros, dentre eles: Cada homem é uma raça; Estórias abensonhadas; Contos do nascer da terra; Um rio chamado tempo, uma casa chamada terra; e O outro pé da sereia.
} 
Não passe a mão pelas fotos que se estragam. Elas são o contrário de nós: apagam-se quando recebem carícias.

Dulcineusa queixa-se que ela nunca aparece em nenhuma foto. Sem remorso, empurro mais longe a ilusão. Afinal, a fotografia é sempre uma mentira. Tudo na vida está acontecendo por repetida vez.

- Engano seu. Veja esta foto, aqui está a Avó. (..... ${ }^{2}$

Quando apreciamos determinadas fotografias nos vemos, quase sem perceber, mergulhados na imagem, e nos colocamos a criar a sua narrativa. Trata-se de um exercício mental de reconstituição quase intuitivo. É uma forma de reativar lembranças jacentes da memória, emergi-las e lhes dar corpo no presente, assim como de atualizálas, principalmente quando nos deparamos com fotografias de pessoas conhecidas que fazem parte da nossa história.

Diante de fotografias pessoais, álbuns familiares, aparentemente só se incluem situações felizes, pois a lembrança destacará apenas situações que lhe convier, momentos que lhe forem agradáveis, como celebrações, viagens, férias, etc. Segundo Fontcuberta, “(...) fotografamos para reforçar a felicidade desses momentos. Para afirmar aquilo que nos dá prazer, para cobrir ausências, para deter o tempo.”3 Assim como fez Dulcineusa e o neto, que pegaram o álbum e folhearam-no no intuito de reter o tempo e de preencher o vazio a partir de construções imagéticas e imaginárias.

Dessa maneira, a imagem fotográfica incorpora tanto o real quanto o irreal. Ela deixa de ser vista somente como um registro, índice, uma maneira de se eternizar o material aprisionado e passa a ser uma forma de se acessar momentos vividos, capturados, construídos, e, muitas vezes, imaginados, podendo ser tanto uma maneira de dar veracidade a construções fictícias, quanto de assumir o lugar de objeto que retrata, comprovando a veracidade dos fatos.

A ideia de a fotografia ser um ícone que dá veracidade aos acontecimentos e comprova a existência das coisas vem desde a sua “democratização”, em meados do ano de 1930, período em que a vida passa a ser registrada muito mais pelas imagens do que pelos livros, cartas ou diários, e a memória individual e familiar passa a ser construída tendo por base o suporte imagético. Nesse contexto, a câmera começa a funcionar como uma extensão do olhar, adquirindo o status não de um objeto (uma imagem), e, sim, de uma maneira de ver e de pensar; "uma maneira de se ver no mundo”. Dessa forma, a redução do processo ao seu dispositivo físico vem sustentar "uma concepção metafísica

\footnotetext{
${ }^{2}$ COUTO. Um rio chamado tempo, uma casa chamada terra, p. 49.

${ }^{3}$ FONTCUBERTA. Vidência e evidência, p. 12.
} 
binária: de um lado, a representação das coisas do mundo; de outro, o testemunho de sua existência. Oscila entre a essência da fotografia e a existência das coisas.”4

O que interessa aqui é desconstruir a ideia de a fotografia ser um objeto de apreensão do real, pois o que se é interessante nessa proposta é compreendê-la como apreensão da perda, como um rastro de algo que possivelmente esteve ali e que pode ser reconstruído a qualquer momento, mas nunca da mesma forma, e sim por uma nova releitura, de um novo ângulo, por uma nova luz.

É interessante pensar que, “(...) ao ver, temos a impressão de ganharmos alguma coisa, mas na verdade, devemos nos abrir para olharmos o que não vemos e o que não mais veremos, e o que perdemos”, pois “(...) ver é sentir que algo inelutavelmente nos escapa, isto é: ver é perder, e tudo está aí."5

Seria assim outra forma de ver a fotografia como um objeto visual que mostra a diluição e o desaparecimento dos corpos. Um momento congelado pelo tempo e pelo espaço que pode ser apreendido, e, ao mesmo tempo, desfeito de variadas formas, possibilitando a transformação da imagem em um substituto imaginário do real, deslocando-a, podendo, assim, tocar o intocável, e ver o que não está presente. Perceber que "o que é essencialmente distante é o inacessível, e a principal qualidade de uma imagem que serve ao culto é ser inacessível. Por sua própria natureza, ela é sempre distante por mais próxima que esteja.”6

Crer na fotografia como testemunho de alguma coisa implica, em primeiro lugar, precisamente isso, crer, ter fé. O realismo fotográfico e seus valores subjacentes são uma questão de fé. Porque não há um indício racional convincente que garanta que a fotografia, por sua própria natureza, tenha mais valor como recordatório que o laço feito num dedo ou a relíquia. ${ }^{7}$

No universo de ver a fotografia como um objeto de crença, as fotografias de família, encontradas, muitas vezes, organizadas em álbuns, servem para revisitarmos esse intocável. Segundo Joan Fontcuberta, ${ }^{8}$ “(...) o princípio básico tanto da memória quanto da fotografia é o de que as coisas têm que morrer de forma ordenada para viver para sempre (...)"; talvez por isso ordenamos nossas fotografias em álbuns e

\footnotetext{
${ }^{4}$ ROUILLÉ. A fotografia: entre documento e arte contemporânea, p. 199.

${ }^{5}$ DIDI-HUBERMAN. O que vemos, o que nos olha, p. 34.

${ }^{6}$ DUBOIS. O ato fotográfico e outros ensaios, p. 311.

${ }^{7}$ FONTCUBERTA. Vidência e evidência, p. 14.

${ }^{8}$ FONTCUBERTA. Vidência e evidência, p. 15.
} 
construímos psicológica e cronologicamente uma narrativa para eternizá-las. Dessa forma, acreditamos que, com isso, não esqueceremos a nossa história.

Olhar uma fotografia e reconhecer que ela representa algo imaginário faz parte do ritual familiar, mesmo que inconscientemente. Folhear um álbum é reconstruir histórias a partir de nossas lembranças; alinhavar os momentos felizes e as pessoas queridas; ignorar o real; preencher o vazio deixado pela ausência. É uma forma de resgatar e reconstituir aquilo que se foi através da imaginação e dos sentimentos, recorrendo, assim, à nossa memória.

Em VE(lar), trabalho por mim desenvolvido, o álbum é revisitado a partir da imagem mental que tinha em minha memória de acontecimentos passados, que foram reconstruídos a partir do contato com meu álbum familiar. A partir daí foram selecionadas fotos que, de alguma forma, detinham minha atenção. Então, elas foram remexidas, apropriadas, reconstruídas, e sua narrativa foi refeita, desordenando, assim, o raciocínio lógico da imagem fotográfica, que já não era mais uma forma de se "ver o real”. Como no álbum de Dulcineusa, ${ }^{9}$ em que as fotos estão ausentes, e com isso ela e o neto começam a criar e recriar suas lembranças. Porém, no caso de VE(lar), as fotos existiam como matéria, mas o que se ausentou foi o rosto, que foi apagado pela luz.

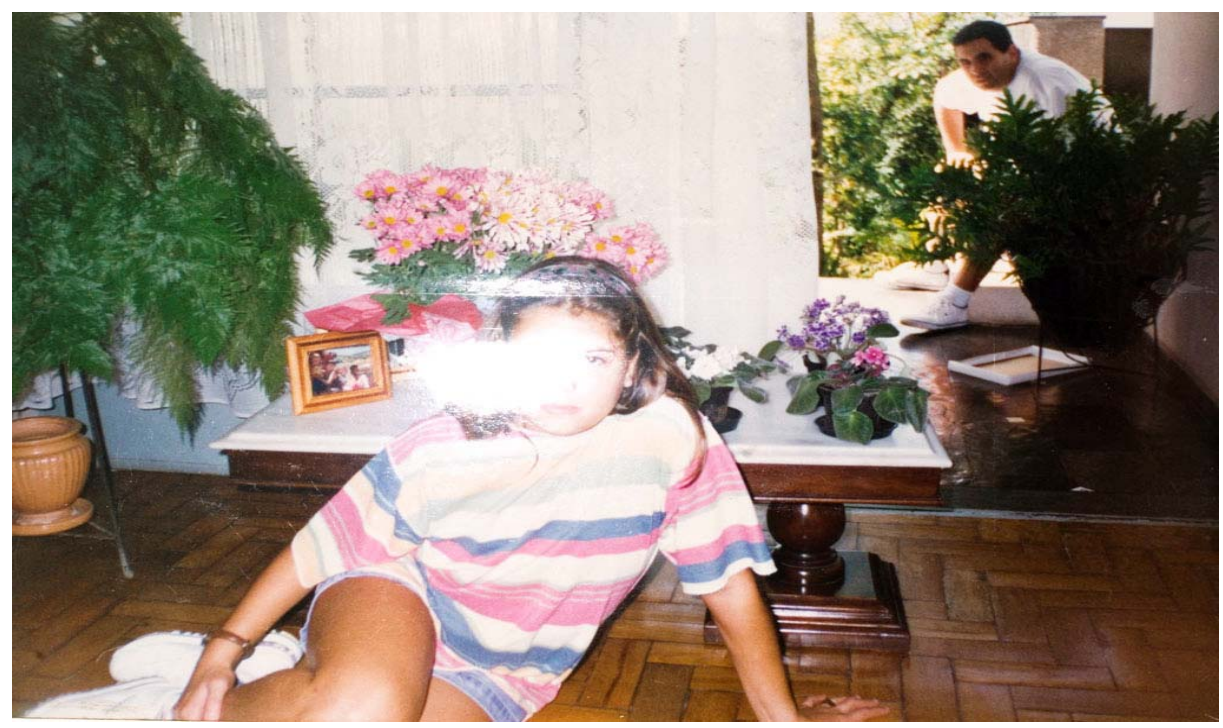

FIG. 1 - Camila Otto: VE(lar), 2010, C-Print, 10x15 cm

\footnotetext{
${ }^{9}$ Personagem do romance Um rio chamado tempo, uma casa chamada terra de Mia Couto citado neste artigo.
} 
Pensando nesse aspecto da luz na construção da imagem, aproximo o trabalho com o mito de Orfeu, porque, assim como Eurídice se desfez quando os olhos de Orfeu captaram a luz emanada por ela, o rosto se desfez quando a câmera captou a luz refletida pela imagem fotográfica. ${ }^{10}$

(...) de volta dos Infernos, Orfeu, que não agüenta mais, no auge de seu desejo, transgride finalmente o proibido. Ao sair das Trevas, volta-se para sua Eurídice, a vê e, na fração de segundo em que seu olhar a reconhece e a apreende na Luz, de uma só vez, ela desaparece. Desse modo, qualquer fotografia, no momento em que é feita, remete para sempre seu objeto ao reino das sombras. ${ }^{11}$

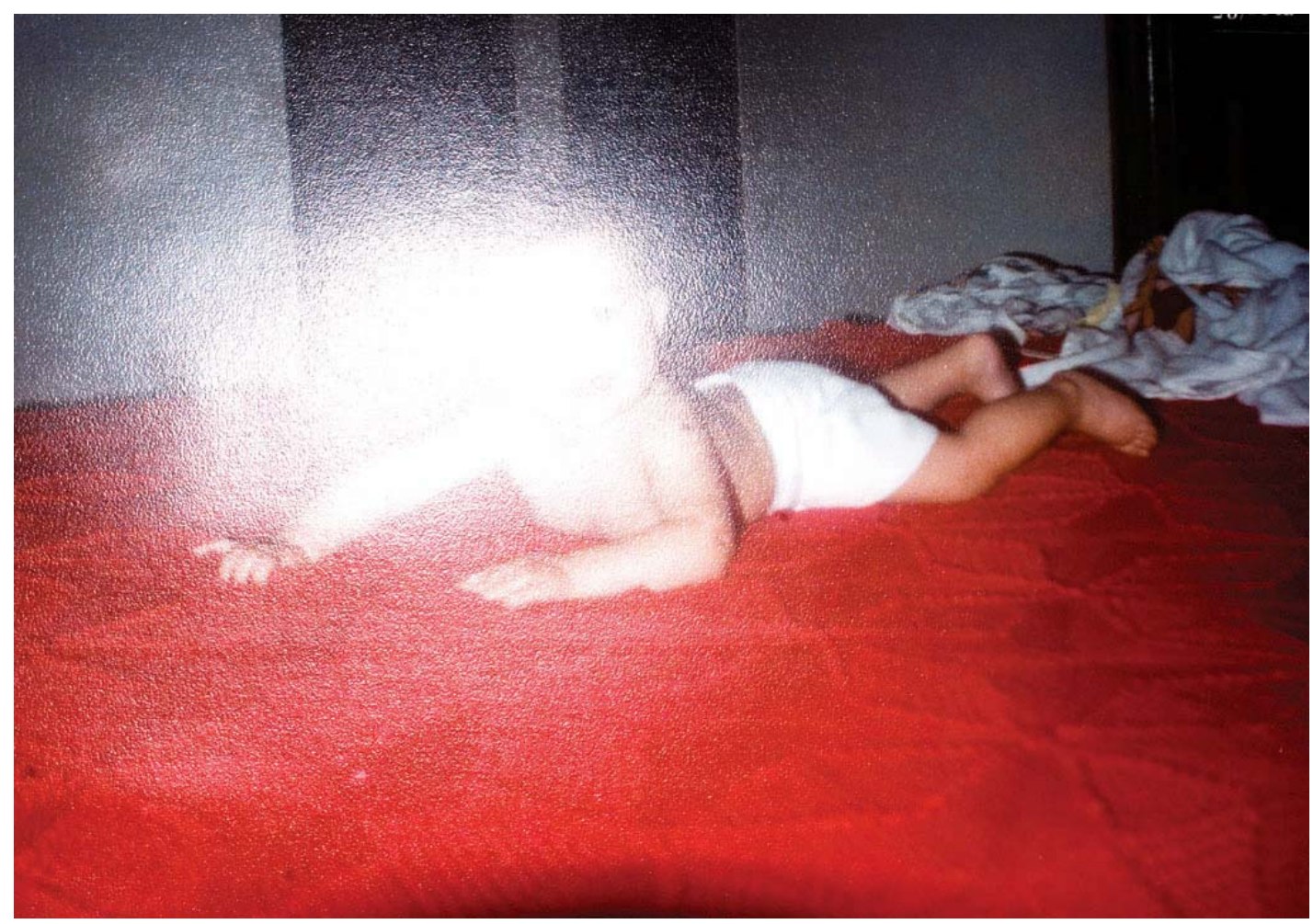

FIG. 2 - Camila Otto: VE(lar), 2010, C-Print, 10x15 cm

Orfeu perde Eurídice através da apreensão da luz, assim como o rosto se desfaz a partir da luz emitida pela câmera ao fotografar os retratos do álbum de família. Dessa maneira, tento afirmar, em VE(lar), que fotografar é não ver. Roland Barthes assim define: "Seja o que for que ela dê a ver e qualquer que seja a maneira, uma foto é

${ }^{10} \mathrm{O}$ trabalho consiste em fotografar os retratos arquivados no álbum de família. Esse ato implica usar o flash da câmera, para que o feixe de luz emitido seja refletido para a câmera no momento da captação da imagem, e a partir de uma angulação específica, consiga-se o apagamento do rosto.

${ }^{11}$ DUBOIS. O ato fotográfico e outros ensaios, p. 312. 
sempre invisível: não é ela que vemos.” ${ }^{„ 12}$ Nesse sentido, tudo que ela nos dá a ver gira em torno da ausência e da morte; ela instiga nosso desejo de ver o que não pode e nem deve ser visto outra vez.

Desse modo, a foto pode ser vista como uma forma de refazer fatos e negar acontecimentos que não se queira lembrar. É como se fosse um túmulo sem corpo, um vazio preenchido por uma matéria imaginária, pelas lembranças que utilizamos para preencher nossas angústias. Nas palavras de Didi-Huberman: "Uma espécie de horror ou de denegação do cheio, isto é, do fato de este volume, diante de nós, estar cheio de um ser semelhante a nós, mas morto, e deste modo cheio de angústia que nos segreda nosso próprio destino.”13

Tentar refazer histórias e trazer ao presente o passado, através da fotografia, é uma forma que encontramos de preencher o vazio com uma presença imaginária, mas que possui um limite de acesso, pois, para Blanchot, “(...) a distância nos detém; essa distância que é então profundidade não viva, indisponível, lonjura inapreciável que se torna como que a potência soberana e derradeira das coisas”. ${ }^{14}$ É o intangível e inatingível; não se pode tocar o ausente, porque, ao desaparecer, o morto passa a existir somente a partir de imagens que o podem representar, pela sua aparição. Dessa maneira, sua presença se torna possível somente a partir do olhar, isto é, da sua imagem fotográfica.

Na procura desse intangível, em VE(lar), olhei-me através do espelho, e, ao fazê-lo, não conseguia ver o meu rosto; o que via era apenas uma impossibilidade de decifrar a luz que de mim refletia.

Nesse momento lembrei-me de um personagem de "O espelho", de Guimarães Rosa, que passa pelo processo de olhar para si através de uma imagem que lhe reproduz e nada ver, encarar-se e ver o nada através do espelho. "Voltei a querer encarar-me. Nada. E o que tomadamente me estarreceu: eu não via os meus olhos. No brilhante e polido nada, não se me espelhavam nem eles!”"15 Assim, adentro-me num universo que já não me reconhecia. Não fazia mais parte daquele álbum; será que deixei de existir?

\footnotetext{
${ }^{12}$ BARTHES. A câmara clara: nota sobre a fotografia, p. 16.

${ }^{13}$ DIDI-HUBERMAN. O que vemos, o que nos olha, p. 38.

${ }^{14}$ BLANCHOT. O espaço literário, p. 263.

${ }^{15}$ ROSA. Primeiras estórias, p. 70.
} 
A descontextualização não só modifica um valor de uso, mas, sobretudo pulveriza a noção mesma de que a fotografia é a prova de algo, o suporte de uma evidência. Porém, evidência de quê? Talvez evidência apenas de sua própria ambigüidade. O que fica então do documento? ${ }^{16}$

Em VE(lar), a fotografia foi revisitada e transformada. Dela restou a possibilidade de se recriar, pois a foto já não servia para representar o real. Fiz do álbum um objeto de descaso, e, segundo o senso comum, foi um ato horrível. Desfiz da imagem e transformei-a em um objeto de horror, em algo ambíguo e sem vida.

Roland Barthes esclarece-nos: “(...) se a fotografia se torna horrível, é porque ela certifica, se assim podemos dizer, que o cadáver está vivo, enquanto cadáver: é a imagem viva de uma coisa morta." ${ }^{17}$ Por isso, ao me desfazer do rosto deixei claro que a imagem presente no álbum e revisitada para dar vida às lembranças, na verdade, é a representação de algo passado, que nunca mais poderá ser revivido pelo real, e que é algo que potencializa a morte.

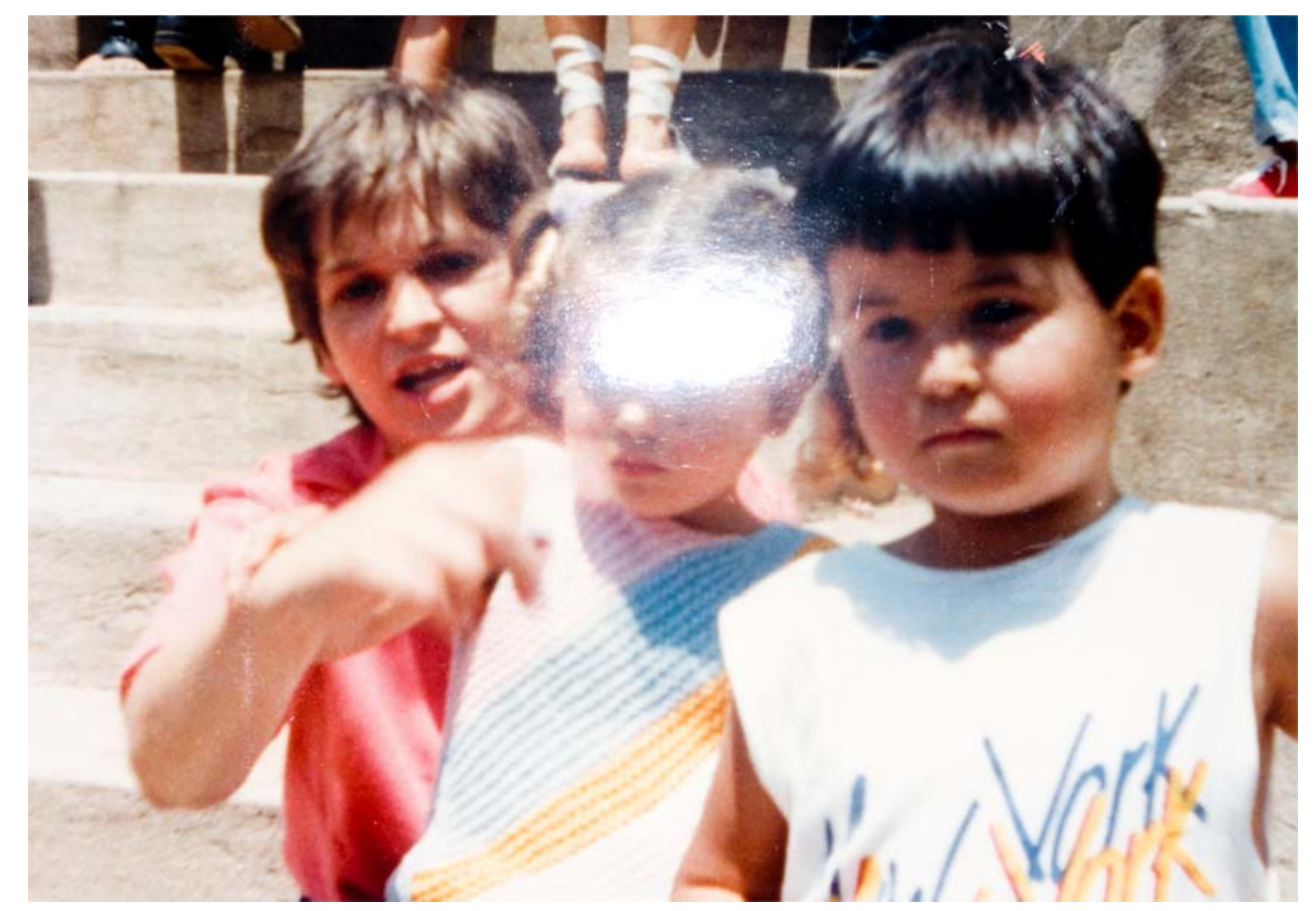

FIG. 3 - Camila Otto: VE(lar), 2010, C-Print, 10x15 cm

\footnotetext{
${ }^{16}$ FONTCUBERTA. Vidência e evidência, p. 13.

${ }^{17}$ BARTHES. A câmara clara: nota sobre a fotografia, p. 118.
} 
Sabe-se que, "num certo momento", a potência da morte faz com que ela não se mantenha mais no belo lugar que lhe atribuíram. “O cadáver poderá estar tranqüilamente estendido em seu leito de velório que nem por isso deixará de estar também por toda a parte, no quarto, na casa (...)”, ${ }^{18}$ ou quem sabe, dentro do álbum familiar.

Sendo assim, o morto (a imagem representada na fotografia) pode estar em qualquer lugar, e para isso só se faz necessário imaginar, pois ele se torna imagem a partir do momento em que a sua existência como matéria se desfaz, ao mesmo tempo que se abre.

A atração que temos pelo álbum e suas imagens venha talvez daí: um objeto de crença no qual encontramos imagens que se abrem ao infinito, que visitam nossa memória, revisitam nosso passado e duplicam a nossa imagem no tempo e no espaço, preenchendo-nos o vazio e a necessidade de identificação com a nossa própria imagem, de se ver como os outros nos veem. De procurar a semelhança e ao mesmo tempo a diferença, na busca da essência do eu.

Essa procura através dos retratos é uma tentativa de preenchimento do desconhecido, do desaparecido. É uma forma de construirmos a nossa imagem a partir de relatos, lembranças e narrativas. Sendo assim, eis um fragmento de Gregory Bateson, em que nos narra, de uma forma quase que imagética, o que acabo de discorrer:

Um homem se questionava sobre o espírito presente não na natureza, mas no fundo do espelho diante do qual se reencontrava cada manhã. Ele perguntou-lhe, fixando-o profundamente: "Será que um dia você poderá ver como eu te vejo, ver como um ser humano?” O espelho começou a refletir longamente e analisar quais seriam suas maneiras próprias de ver e de olhar. Enfim, ele imprimiu sua resposta sobre o fundo do estanho, como todos os espelhos fazem. O homem extasiou quando descobriu essas palavras, impecavelmente traçadas sobre a superfície polida: “Isto-me-lembrar-uma-história?” Aturdido ainda, o homem lhe perguntou: “O que é uma história?” $\mathrm{O}$ espelho lhe respondeu: "São pequenos nós, maneiras de ser atadas e reatadas, modos de ser reunidos, como você e eu estamos neste momento." Acrescentou:

- Minha história não é apenas a sua, a de seu pai e de sua mãe, a história do feto que você foi e - antes disso - a história do nascimento da animalidade e a história da emergência da vida; é também a história do nascimento da sombra e da luz, a história dos seus olhos que aprenderam a ver e não poder ver, a história das representações humanas e da perspectiva, a história das imagens que fabrico e das imagens que você concebe para tentar se entender. Todas essas

\footnotetext{
${ }^{18}$ BLANCHOT. O espaço literário, p. 261.
} 
histórias são escritas em mim e em você, mesmo que elas não sejam, dentro de nós, imediatamente legíveis.

O espelho, então, estremeceu e, em seguida, esfacelou-se no chão. Perante o homem, havia apenas uma fotografia. ${ }^{19}$

A partir desse fragmento, podemos propor que a realidade é uma narrativa construída pelos momentos vividos e fixada pelas sensações e, principalmente, pela imagem. Ou seja, a realidade é substituída pela fotografia que se apossa do status de espelho do real. Perceber a diferença entre imagem e realidade torna-se uma tarefa complexa. Por isso, ambos - o espelho e a fotografia - não devem ser vistos como o real, pois eles apenas refletem o real, materializam uma presença distorcida. Olhar algo que foi refletido é olhar algo duplicado e alterado pela presença da luz, do tempo e de uma matéria presente não mensurável. É olhar a si próprio através da ação de um suporte que é capaz de refletir algo, e ao mesmo tempo alterá-lo.

Para Maurice Blanchot, ${ }^{20}$ olhar a si mesmo (acrescento, através da foto) se assemelha a olhar o nada. Dessa maneira, abandona a ideia da simples semelhança e percebe que por trás dela nada existe como matéria, dando a ela só aquilo que se entregou à imagem, ao imaginário. Ou seja, ao seu próprio fantasma, que já não tem outra vida senão a do outro.

A imagem pode, certamente, ajudar-nos a recuperar idealmente a coisa, de que ela é então a sua negação vivificante, mas que, ao nível para onde nos arrasta o peso que lhe é próprio, corre também o constante risco de nos devolver, não mais à coisa ausente, mas à ausência como presença, ao duplo neutro do objeto em que a pertença ao mundo se dissipou: uma duplicidade não é tal que se possa pacificá-la por um "ou isto ou aquilo" capaz de autorizar uma escolha e de apagar da escolha a ambigüidade que a torna possível. Essa duplicidade devolve a um duplo sentido sempre mais inicial. ${ }^{21}$

Com isso, podemos pensar que o homem é feito à sua imagem, ou melhor isto é, “o homem é desfeito segundo a sua imagem”, 22 ou podemos pensar que ele é refeito a cada vez que se encontra com sua imagem, com seu duplo. Dessa forma, conviver com a imagem fotográfica é lidar com a apreensão do real, e, ao mesmo tempo, com o irreal, com as coisas que desaparecem, e que serão impossíveis de serem revividas; daí o seu fascínio e sua angústia.

\footnotetext{
${ }^{19}$ BATESON citado por SAMAIN. O fotográfico, p. 13.

${ }^{20}$ BLANCHOT. O espaço literário.

${ }^{21}$ BLANCHOT. O espaço literário, p. 264.

${ }^{22}$ BLANCHOT. O espaço literário, p. 262.
} 
Nesse sentido, a imagem sempre carregará o seu duplo com ela, pois vem daí seu sentido de existência, de representar algo. Assim, sucessivamente, haverá nela algo latente, que é o seu potencial de simular o visível e ao mesmo tempo o invisível, o indizível, o imaginário.

Sempre haverá uma parcela de imagem invisível. Ou melhor, sempre haverá invisível na imagem. Sempre haverá uma espécie de latência no positivo mais afirmado, a virtualidade de algo que foi perdido (ou transformado) no percurso. Nesse sentido, a foto sempre será assombrada. Sempre será, em (boa) parte, uma imagem mental. ${ }^{23}$

Então, ao olhar um retrato, a pessoa que olha está sempre à procura de uma relação entre ela e a imagem; entre ela e o outro; entre ela e a imagem mental do outro ou dela mesma. E ao olhar o morto, o retratado, o ser se coloca, sem perceber, num exercício de olhar além da matéria e da imagem.

É uma maneira de tentar atingir o inatingível, como uma tentativa de ver o que está além do túmulo, na procura do inexistente presente na imagem, e em busca de uma resposta para própria existência. Nesse momento a imagem se abre para novos mundos.

Eis por que o túmulo, quando o vejo, me olha até o âmago - e nesse ponto, aliás, ele vem perturbar minha capacidade de vê-lo simplesmente (...). É a angústia de olhar o fundo - o lugar - do que me olha, a angústia de ser lançado à questão de saber (na verdade, de não saber) o que vem a ser meu próprio corpo, entre sua capacidade de fazer volume e sua capacidade de se oferecer ao vazio, de se abrir. ${ }^{24}$

Buscando esse vazio, essa abertura através da matéria, uso em VE(lar) o rosto, ou seja, desfaço dele, e faço com que passe a ser reduzido à percepção, encontrando-se nu. Questiono essa relação que temos com a face e nossa forma de identificação do outro e de nós mesmos.

Quanto maior sua satisfação, mais longe está de ser satisfeito. O Outro é rosto (aquilo que não pode ser reduzido à compreensão) e o rosto é “aquilo que não se pode matar". É, ao mesmo tempo, riqueza e pobreza, domesticação e submissão, fragilidade e poder. O Outro, portanto, é apenas rosto e ao mesmo tempo não tem rosto algum. ${ }^{25}$

Na busca desse rosto, do outro e de si mesmo, adentramos então na imagem fotográfica e esperamos que ela nos dê a reposta, como na célebre frase "- Espelho,

\footnotetext{
${ }^{23}$ DUBOIS. O ato fotográfico e outros ensaios, p. 326.

${ }^{24}$ DIDI-HUBERMAN. O que vemos, o que nos olha, p. 38.

${ }^{25}$ OLIVEIRA. Verbete: rosto (em Levinas).
} 
espelho meu, tem alguém mais bela do que eu?” Estamos sempre na busca do outro, que é o eu idealizado que carregamos com nós.

Diante da imagem fotográfica só vemos o que nos permitimos ver; e muitas vezes só queremos ver a nós mesmos e aos outros em um movimento especular idealizado, quase sempre a partir de um rosto vazio que é preenchido por nossas necessidades de visualizar verdades imaginárias.

A foto? Não acreditar (demais) no que se vê. Saber não ver o que se exibe (e que oculta). E saber ver além, ao lado, através. Procurar o negativo no positivo, e a imagem latente no fundo do negativo. Ascender da consciência da imagem rumo à consciência do pensamento. Refazer de novo o caminho do aparelho psíquicofotográfico, sem fim. Atravessar as camadas, os extratos, como o arqueólogo. Uma foto não passa de uma superfície. Não tem profundidade, mas uma densidade fantástica. Uma foto sempre esconde a outra, atrás dela, sob ela, em torno dela. Questão de tela. Palimpsexto. ${ }^{26}$

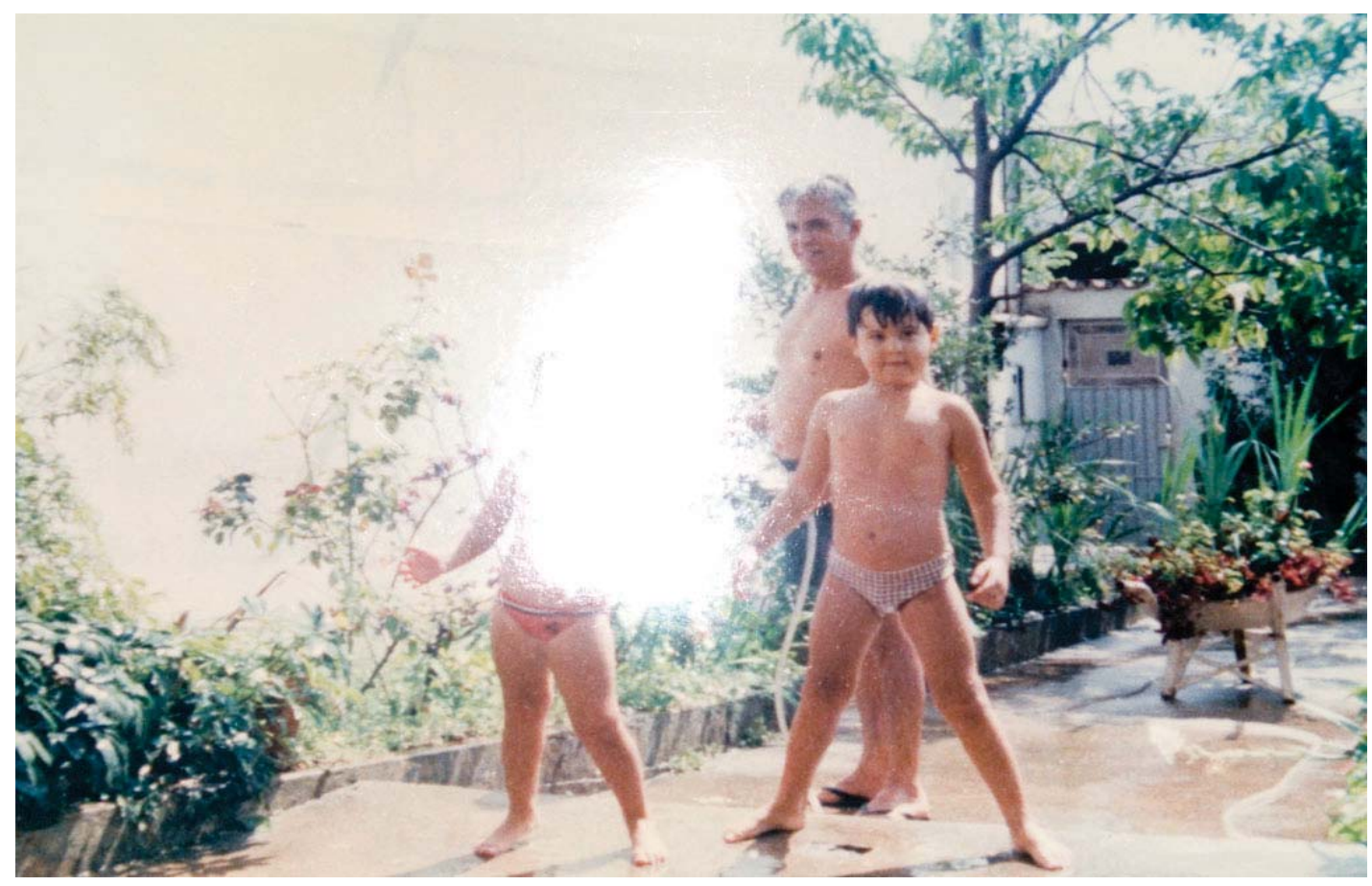

FIG. 4 - Camila Otto: VE(lar), 2010, C-Print, 10x15 cm

Construindo uma imagem que Georges Didi-Huberman chama de “(...) imagem de memória e crítica ao mesmo tempo, imagem de uma novidade radical que reinventa o originário, uma imagem dialética que através do trabalho crítico da memória,

${ }^{26}$ DUBOIS. O ato fotográfico e outros ensaios, p. 326. 
confronta tudo que resta como indício de tudo o que foi perdido", ${ }^{27}$ proponho que VE(lar) não se detenha diante da imagem representada, e que a memória possa agir nele de uma forma a dar-lhe corpo para voar pela vastidão do pensamento, e que se comporte como um palimpsexto que, mesmo carregando vestígios de histórias passadas, se abre a novas possibilidades.

Sugiro que possamos esquecer, pois é a partir do esquecimento que podemos exercitar nosso pensamento na reconstrução de fatos, na criação de novas histórias e possibilidades de interpretação. Como bem diz Joan Fontcuberta: "lembrar quer dizer selecionar certos capítulos de nossa experiência e esquecer o resto. Não há nada tão doloroso quanto a lembrança exaustiva e indiscriminada de cada um dos detalhes de nossa vida.” ${ }^{28}$ Imagina se não pudéssemos esquecer as pessoas, os acontecimentos, os momentos felizes e tristes, lugares, seríamos com Ireneo Funes, personagem do conto “Funes - o mentiroso”, de Jorge Luis Borges, que nada esquece. E que a partir dessa incapacidade de não esquecer as coisas não conseguia pensar, mas apenas armazenar dados, codificá-los, e quando necessário, acessá-los. "Suspeito, entretanto, que não era muito capaz de pensar. Pensar é esquecer diferenças, é generalizar, abstrair. No abarrotado mundo de Funes não havia senão pormenores, quase imediatos.”29

Para terminar, como lembrar cada detalhe do rosto? E por que não deixá-lo livre? Para se abrir a novas formas, se reinventar, permitir à imagem a possibilidade de retornar à pergunta que lhe fazem. Para que ela não carregue uma árdua tomada de poder e de posse da verdade.

\footnotetext{
${ }^{27}$ DIDI-HUBERMAN. O que vemos, o que nos olha, p. 178.

${ }^{28}$ FONTCUBERTA. Vidência e evidência, p. 12.

${ }^{29}$ BORGES. Fiç̧ões, p. 124-125.
} 


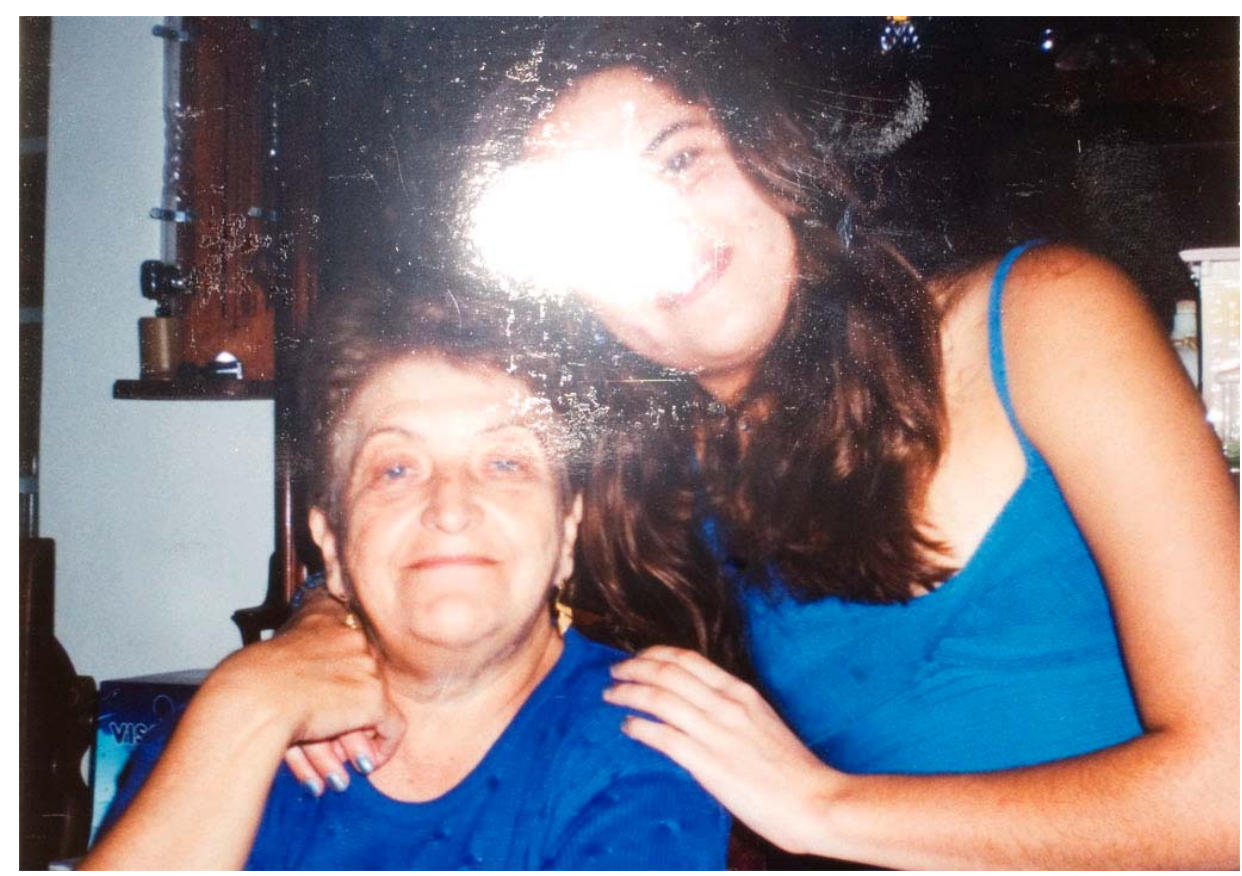

FIG. 5 - Camila Otto: VE(lar), 2010, C-Print, 10x15cm.

\begin{abstract}
The present article discusses some concepts related to issues as “image”, "photography" and "memory". It also goes over the photography while it is seen as a doc and an object of belief. Yet, it puts into discussion its importance towards the memory, in family albums and into the imagery individual's formation, besides commenting on the dual character of the photography, which allows constructing narratives, reviewing histories and proposing new approaches and interpretation to the image. All this content will be discussed through VE(lar), job of my authorship.
\end{abstract}

\title{
KEYWORDS
}

Image, photography, memory, family album, ambiguity

\section{REFERÊNCIAS}

BARTHES, Roland. A câmara clara: nota sobre a fotografia. Trad. Júlio Castañon Guimarães. Rio de Janeiro: Nova Fronteira, 1984. 
BERGSON, Henri. Matéria e memória: ensaio sobre a relação do corpo com o espírito. Trad. Paulo Neves da Silva. São Paulo: Martins Fontes, 1990.

BLANCHOT, Maurice. O espaço literário. Trad. Álvaro Cabral. Rio de Janeiro: Rocco, 1987.

BORGES, Jorge Luis. Fiç̧ões. Trad. Carlos Nejar. Porto Alegre: Globo, 1972.

BOSI, Ecléa. Memória e sociedade: lembranças de velhos. 11. ed. São Paulo: Companhia das Letras, 2004.

BURKE, Peter. Testemunha ocular: história e imagem. Trad. Vera Maria Xavier dos Santos. Bauru, SP: Edusc, 2004.

CALVINO, Italo. Coleção de areia. Trad. Maurício Santana Dias. São Paulo: Companhia das Letras, 2010.

CARVALHO, Bernardo. O mundo fora dos eixos. São Paulo: Publifolha, 2005.

COUTO, Mia. Cada homem é uma raça: estórias. 8. ed. Lisboa: Caminho, 2002.

COUTO, Mia. Contos do nascer da terra. 5. ed. Lisboa: Caminho, 2002.

COUTO, Mia. Estórias abensonhadas: contos. 7. ed. Lisboa: Caminho, 2003a.

COUTO, Mia. Um rio chamado tempo, uma casa chamada terra. São Paulo: Companhia das Letras, 2003b.

COUTO, Mia O outro pé da sereia. São Paulo: Companhia das Letras, 2006.

COUTO, Mia. Antes de nascer o mundo. São Paulo: Companhia das Letras, 2009.

DELEUZE, Gilles. Lógica do Sentido. Trad. Luiz Roberto Salinas Fortes. São Paulo: Perspectiva, 1974.

DIDI-HUBERMAN, Georges. O que vemos, o que nos olha. 2. ed. Trad. Paulo Neves. São Paulo: Editora 34, 2010.

DUBOIS, Philippe. O ato fotográfico e outros ensaios. Trad. Marina Appenzeller. Campinas: Papirus, 1993.

DURAND, Gilbert. O imaginário: ensaio acerca das ciências e da filosofia da imagem. Trad. René Eve Levié. Rio de Janeiro: DIFEL, 1998.

FABRIS, Annateresa. Identidades virtuais: uma leitura do retrato fotográfico. Belo Horizonte: Ed. UFMG, 2004.

FLUSSER, Vilém. Filosofia da caixa preta: ensaios para uma futura filosofia da fotografia. Trad. Júlio Castñon Guimarães. São Paulo: Hucitec, 1985.

FONTCUBERTA, Joan. Vidência e evidência. Revista Imagens, Núcleo Temático, Editora Unicamp, n. 7, p. 8-15, maio/ago. 1996.

FONTCUBERTA, Joan. La câmara de Pandora: la fotografia después de la fotografia. Trad. Maria Alzira Brum Lemos. Barcelona: Editorial Gustavo Gili, 2010a.

FONTCUBERTA, Joan. O beijo de Judas: fotografia e verdade. Trad. Maria Alzira Brum Lemos. Barcelona: Editorial Gustavo Gili, 2010b.

FOUCAULT, Michel. Isto não é um cachimbo. 3. ed. Trad. Jorge Coli. Rio de Janeiro: Paz e Terra, 2002. 
GUIMARÃES, César. Imagens da memória: entre o legível e o visível. Belo Horizonte: Ed. UFMG, 1997.

HALBWACHS, Maurice. A memória coletiva. Trad. Laís Teles Benoir. São Paulo: Centauro, 2004.

KOSSOY, Boris. Fotografia e história. São Paulo: Ática, 1989.

KRAUSS, Rosalind. O fotográfico. Trad. Anne Marie Davée. Barcelona: Gustavo Gili, 2002.

MARTINS, Jose de Souza. Sociologia da fotografia e da imagem. São Paulo: Contexto, 2008.

OLIVEIRA, Rodrigo Lopes de Barros. Verbete: Rosto (de Lévinas), SOPRO: Panfleto político cultural, n. 8 abr. 2009. Disponível em: <http://www.culturaebarbarie.org/sopro/verbetes/rosto.html>. Acesso em: 1 nov. 2011.

RICEEUR, Paul. A memória, a história, o esquecimento. Trad. Alain François. Campinas: Ed. Unicamp, 2007.

ROSA, João Guimarães. Primeiras estórias. 16. ed. Rio de Janeiro: Nova Fronteira, 1985.

ROUILLÉ, André. A fotografia: entre documento e arte contemporânea. Trad. Constancia Egrejas. São Paulo: Ed. SENAC-São Paulo, 2009.

SAMAIN, Etienne Ghislain (Org.). O fotográfico. 2. ed. Trad. Rubén Masera. São Paulo: Hucitec/Editora SENAC-São Paulo, 2005.

SARTRE, Jean-Paul. A imaginação. 4. ed. Trad. Luiz Roberto Salinas Fortes. São Paulo: Difusão Europeia do Livro, 1973.

SCHAEFFER, Jean-Marie. A imagem precária: sobre o dispositivo fotográfico. Trad. Eleonora Bottmann. Campinas: Papirus, 1996.

SELIGMANN-SILVA, Márcio. História, memória, literatura: o testemunho na era das catástrofes. Campinas: Editora Unicamp, 2003.

SILVA, Armando; DOLINSK MARTHA, Sandra (Org.). Álbum de família - a imagem de nós mesmos. São Paulo: Editora SENAC-São Paulo/Edições SESC SP, 2008.

SONTAG, Susan. Diante da dor dos outros. Trad. Ruben Figueiredo. São Paulo: Companhia das Letras, 2003.

SONTAG, Susan. Sobre fotografia. Trad. Rubens Figueiredo. São Paulo: Cia das Letras, 2004.

SOUZA, Eudoro. História e mito. Brasília: Editora Universidade de Brasília, 1981.

SOULAGES, François. Estética da fotografia: perda e permanência. Trad. Iraci D. Poleti e Regina Salgado Campos. São Paulo: Editora SENAC-São Paulo, 2010. 